\title{
Payout and Firm's Catering
}

\author{
Maria Elisabete Duante Neves ${ }^{1 *}$
}

\begin{abstract}
:
This paper is built upon the predictions of the catering theory of dividends and examines whether investor sentiments exert significant influence on corporate dividend policy.

Accordingly, we propose a dividend model that incorporates a variable at the firm-level proxy for the catering effect.

Estimation of the model using the GMM shows that firms in Eurozone countries cater to their investors' sentiments, and the model provides evidence supporting the catering model.

Additionally, we show an interaction effect between catering and firm characteristics, particularly liquid assets, investment opportunities, and levels of free cash flow.
\end{abstract}

Keywords: Payout, investors' sentiment, Catering, firm characteristics.

JEL Classification: G35

\footnotetext{
${ }^{1}$ Instituto Politécnico de Coimbra - ISCAC, Quinta Agrícola Bencanta 3040-316 Coimbra, Portugal,mneves@iscac.pt

* My ackowlegment to CETRAD research center and the Foundation for Science and Technology. This work is supported by: European Structural and Investment Funds in the FEDER component, through the Operational Competitiveness and Internationalization Programme (COMPETE 2020) [Project No. 006971 (UID/SOC/04011)]; and national funds, through the FCT - Portuguese Foundation for Science and Technology under the project UID/SOC/04011/2013.
} 


\section{Introduction}

Corporate dividend policy has long been an issue of interest in the financial literature and, despite the vast body of research on the topic, it remains an open subject to debate. In fact, since the Miller and Modigliani (1961) irrelevance proposition, according to which dividend policies are all equivalent and there is no a policy that can increase shareholder wealth in perfect capital markets, many scholars have offered alternative explanations for dividends in imperfect markets. Despite the vast and mainly US-based literature on this issue ${ }^{2}$, there is no definitive answer as to why investors demand dividends.

One of the most recent arguments that cast doubt on shareholders being indifferent about receiving dividends is based on the behavioral finance literature. According to this literature, investors' psychological characteristics influence conduct in financial markets, and investors' irrational behavior limits the effectiveness of arbitration actions. In fact, models of behavioral finance (Jegadeesh and Titman, 2001; Ritter 2003; Subrahmanyam, 2007) explain the excess volatility and predictability of stock market prices by breaking with the complete rationality hypothesis underlying traditional finance. Within this context, some of the most prominent explanations are based on investor sentiment (Barberis et al., 1998; Daniel et al., 1998; Hong and Stein, 1999; Lamont and Stein, 2006; Coval et al., 2008; Kurov, 2008; Vieira, 2011; Bathia and Bredin, 2013).

Explanations for the tendency to pay dividends in equilibrium clientele theory were first offered by Miller and Modigliani (1961), and Black and Scholes (1974). This theory suggests that changes in dividend policies correspond with changes in investor demand for dividends.

Furthermore, firms have become less likely to pay dividends beyond what could be expected given the changes in their characteristics such as size, profitability and growth opportunities. In fact, Fama and French (2001) find that the decline in the proportion of dividend-paying US firms is not satisfactorily explained by changes in their characteristics and, consequently, that the dividend decision is not entirely explained by the individual characteristics of each firm. Several authors propose alternative explanations for this decline in the propensity to pay dividends. For instance, Banerjee et al. (2007) argue that transaction cost-based clientele effects account for a significant part of the decline in the propensity to pay dividends. Amihud and $\mathrm{Li}$ (2006) also document the phenomenon called "disappearing dividends" by Fama and French (2001), which describes the decrease in the information content of dividends since the mid 1970s, making firms less willing to incur the costs associated with dividend signaling. DeAngelo et al. (2004) base their

\footnotetext{
${ }^{2}$ See, for instance, Fama and French (2001); Koch and Sun (2004); DeAngelo, DeAngelo, and Skinner (2004); Allen and Michaley (2003); Brav, et al. (2005); DeAngelo and DeAngelo (2006, 2007); Boudoukh, et al. (2007); Li and Zhao (2008) or Skinner (2008).
} 
explanation of the disappearing dividends phenomenon on the concentration of dividends in top payers among US firms, as well as on the decline in the frequency of special dividend payments over the last two decades. Brav et al. (2005) find that the higher flexibility of stock repurchases led managers to favor them over dividends, a result corroborated by Skinner (2008).

Interestingly, recent non-US based evidence confirms patterns of dividend payments found in the US. For instance, Denis and Osobov (2008) examine the dividend policies of firms headquartered in the US, the UK, Canada, France, Germany and Japan, and find a declining propensity to pay dividends in all these countries. Von Eije and Megginson (2008) also find that dividend payments in European Union member countries are similar in many ways to those of American firms.

The most innovative and pioneering explanation for the decline in the payment of dividends have its roots in the catering theory of dividends proposed by Baker and Wurgler (2004a). These authors provide empirical evidence that changes in the amounts that firms pay in dividends can be explained by what they term "catering incentives," that is, a measure of market desire for dividend-paying stocks.

The catering theory holds that firms adjust their dividend payouts largely in response to investor demand for dividend-paying stocks. The growing interest in this new theory of dividends suggests the need to better understand its implications and to integrate investor sentiment into dividend models. In fact, whether there is a catering effect on a firm's payout ratio is, as far as we know, an unresolved question, and research on investor sentiment carried out in the last decade some mixed results in this regard.

For example, Baker and Stein (2003) find that investor sentiment measures are highly correlated with, and have predictive power for, future market returns. Wang et al. (2006) detect influence from market returns as well as from volatility on future values through sentiment measures. Kumar and Lee (2006) rely on the clientele model derived by Barberis et al. (2005) to test the effect of individual investor sentiment on groups of stocks and find that the returns of individual stocks capture the divergent sentiments of various important investor groups. Li and Lie (2006) further extend and provide support for the catering theory of dividends, and Ferris et al. (2006) find that catering incentives have an important influence on the propensity to pay dividends in the UK.

Moreover, Bulan et al. (2007) evidence that catering incentives explain in partly timing of the dividends initiation. On the contrary, Hoberg and Prabhala (2009) or Kuo et al. (2013) shows that dividend premium loses its explanatory power calling into question the presence of catering incentives. Also, Ferris et al. (2009) find no 
evidence on the presence of catering incentives in corporate decisions for civil law countries $^{3}$.

As we can see the results are mixed and/or inconclusive, and the empirical evidence found is somewhat in conflict with that of the US. For instance, Denis and Osobov (2008) find a declining propensity to pay dividends in France and Germany, which is entirely explained by firm size, profitability, growth opportunities, and the ratio of retained earnings to total equity. They conclude that this result supports the agency cost model over the catering theory model. Similarly, Von Eije and Megginson (2008) find no systematic effects from a country-specific catering variable in the 15 countries of the European Union, which suggests that catering "a priori" is not an important factor influencing European payout policies. These authors conclude, however, that further research is required to learn whether the catering theory is relevant in European countries.

With this need in mind, this paper relies on the assumptions of the catering theory and attempts to empirically validate this strand of the literature in Eurozone member countries. In this way, this paper advances the dividend literature in four directions.

First, we offer new evidence on the determinants of corporate dividend policy by focusing on the catering effect associated with investor sentiment. Given the controversy surrounding this matter, it is of interest to further investigate and make clear the role of catering incentives in dividend policies.

Second, we investigate how the dividend-catering relationship is moderated by firm characteristics, such as the level of liquid assets, investment opportunities, and free cash flow.

Third, the choice of Eurozone countries as the base of our study is significant because previous research on this topic is mainly US-based and, in general, offers support to the catering theory of dividends (see references above). However, recent Eurozone evidence (Denis and Osobov, 2008; Von Eije and Megginson, 2008; Ferris et al., 2009; Kuo et al., 2013) is somewhat conflicting in that it suggests a lack of a catering effect in European firms' dividend policies. This paper thus investigates whether firms in the Eurozone cater to their investors' sentiments, as their US counterparts are shown to do.

Fourth, studying dividend policies in Europe is interesting for several reasons, as pointed out by Von Eije and Megginson (2008) in their European Union study ${ }^{4}$.

\footnotetext{
${ }^{3}$ More evidence on the relevance of investor sentiment in various contexts is provided in Edmans, Garcia, and Norli (2007), Boot, Gopalan and Thakor (2008); De Jong, Duca, and Dutordoir (2013) or Manconi and Massa (2013), among others.

${ }^{4}$ They mention, for instance, the largely segmented corporate governance systems, taxation regimes and financial markets among these countries, and the fact that, despite most of them
} 
Finally, we avoid obtaining biased results in our study by solving the problem of censure of the dependent variable in our model. Note that the payout ratio is a censured variable in that some firms pay dividends, whereas others do not, a problem that is overcome by estimating a Tobit model that yields a prediction of the payout ratio.

We propose a new empirical approach that allows us to measure investor sentiment at the firm level, and this is which most distinguishes this paper from the above works. If a firm's market value is mainly explained by its investment, financing and dividend decisions, hence the residual value captured by the error term of the valuation model should be a measure that serves as a proxy for the firm's investor sentiment. This variable representing the catering effect is then entered a dividend model built on the main contributions from previous research.

The estimation of our dividend model by using the Generalized Method of Moments (GMM) on a sample of firms from Eurozone countries provides interesting results. Consistent with catering arguments, our findings reveal that investor sentiment significantly affects a firm's propensity to pay dividends and, as expected, this effect is positive. That is, investor demand for dividends encourages firms to increase their payouts.

Additionally, our study provides further evidence on the moderating role of certain firm characteristics on the relation between dividends and investor sentiment. Specifically, we find that investor sentiment positively impacts dividends of firms with high liquid assets. Furthermore, our results reveal a positive catering effect only for firms with valuable investment opportunities. Finally, we show that the catering effect is significantly larger in firms with higher levels of free cash flow.

Section 2 introduces a theoretical framework that takes account of the existing literature and the empirical evidence on traditional explanations of dividends, as well as on the catering theory, and presents our hypotheses. Section 3 describes the data and variables used in our analysis. In Section 4, we present our model of dividends and discuss the estimation method. The results are discussed in Section 5, and Section 6 presents our conclusions.

\section{Theories and Hypotheses}

In this section, we first summarize the main contributions from previous research to the debate on the determinants of dividend payments, and we propose our hypotheses concerning these traditional theories of dividends. We next discuss the

sharing a civil foundation of their laws, some of them (such as Ireland in our sample) have common law codes. Note that there is a difference between their study and ours, since some European Union members retain their own currencies throughout their study period while all the Eurozone member countries adopted the euro after 1999. 
key arguments of the catering theory of dividends, which leads us to our hypothesis about the effect of a firm's investor sentiment on its payout ratio.

Traditional theories of dividends:

According to Jensen`s (1986) free cash flow theory, if a firm has cash flow not consumed by positive net present value (NPV) projects, it is better to return the excess cash to shareholders in order to maximize their wealth and to reduce the possibility of these funds being wasted by managers in negative NPV projects. This theory thus predicts that higher free cash flow should lead to higher dividend payments to prevent firms from overinvesting. ${ }^{5}$

The positive relationship between dividends and free cash flow is supported by, for instance, Chaplinsky and Niehaus (1993), and Holder et al. (1998). DeAngelo et al. (2004) show that overinvestment processes worsen in firms that accumulate high proportions of cash and distribute low dividends. In the same vein, Miguel et al. (2005) document the role played by dividends in controlling overinvestment processes in firms with high levels of free cash flow. Consistent with Jensen's (1986) theory and subsequent empirical evidence, the following hypothesis is posed:

Hypothesis 1: There is a positive relationship between a firm's free cash flow and its payout ratio.

The financial literature widely supports the role played by debt and dividends as agency-cost control mechanisms, as they solve the conflict of interest between owners and managers (Grossman and Hart, 1980; Jensen, 1986; Rozeff, 1982; Jensen, 1986), and they mitigate asymmetries of information between firms and potential investors (Ross, 1977; Harris and Raviv, 1991; Lintner, 1956; Bhattacharya, 1979' $\mathrm{Li}$ and Zhao, 2008). This literature suggests that debt and dividends may be somehow related, although the literature in general is not unanimous about the way in which they are related.

On the one hand, the search for a trade-off between costs and benefits leads to a substitution hypothesis based on the minimization of agency conflict without duplicating efforts (Easterbrook, 1984; John and Senbert, 1998). In others words, this hypothesis holds that high leverage makes dividends less valuable, and vice versa. ${ }^{6}$ On the other hand, the alternative hypothesis points to the complementary

\footnotetext{
${ }^{5}$ The overinvestment hypothesis has been confirmed from different perspectives in, for instance, Chen and Ho (1997); Chakraborty, Kazarosian, and Trahan (1999); Del Brio, Perote, and Pindado (2003); Morgado and Pindado (2003) or Fangjian (2010).

${ }^{6}$ Subsequent empirical evidence on the substitutability of debt and dividends as cash flow commitments can be found in Moh'd, Perry, and Rimbey (1995, 1998), and Von Eije and Megginson (2008), who assumed that leverage may help control agency costs, thus reducing the need to distribute cash to shareholders through dividends. According to this view, leverage and cash distributions will be substitutes and a negative relationship between cash dividends and debt ratios is predicted.
} 
use of several mechanisms as the most effective solution to a firm's inefficiencies, because no one of them can be a satisfactory solution in itself without generating additional costs (Jensen, 1989). ${ }^{7}$ These two opposing arguments lead us to pose the following two alternative hypotheses about the relationship between debt and dividends:

Hypothesis 2a: A negative relationship between a firm's leverage and its payout ratio is expected (considering debt as a substitute for dividends).

Hypothesis 2b: A positive relationship between a firm's leverage and its payout ratio is expected (considering debt and dividends as complementary mechanisms).

Lintner (1956) argues that firms seek to maintain dividend stability, and he finds that a firm's earnings are probably the key factor to account for to follow a stable dividend pattern. Accordingly, regular dividends represent an ongoing commitment to distribute cash and, more importantly, a commitment that managers are especially averse to break (Lintner, 1956; Brav et al., 2005).

Consistent with Lintner's arguments, Benartzi et al. (1997) find that changes in dividends are highly correlated with past and current changes in earnings. Along the same line of reasoning, Allen et al. (2000) argue that managers need to explain the reasons for their actions to shareholders and must base their explanations on simple and observable indicators, particularly the level of earnings. More evidence on earnings being a determinant of dividends can be found in, for instance, Nissim and Ziv (2001); DeAngelo et al. (2004); Koch and Sun (2004); Denis and Osobov (2008) and Skinner (2008).

Accordingly, we expect firms to adjust their payout ratios to sudden unexpected increases in earnings, and the following hypothesis is proposed:

Hypothesis 3: The higher the earnings, the higher the payout ratio.

Consistent with the literature (Allen and Michaely, 2003; Aivazian et al., 2003), the nature of a firm's assets influences its dividend policy. Specifically, gross, regular, and non-regular dividend payments are found to be positively related to asset tangibility on the basis that greater tangibility of a firm's assets facilitates its access to public markets, and it thus increases the likelihood that the firm follows Lintner's pattern of dividend policy. Specifically, Aivazian et al. (2003) show that the probability that a firm pays dividends increases with the tangibility of its assets.

\footnotetext{
${ }^{7}$ Consistent with this hypothesis, the results in Eckbo and Verma (1994) show a positive and significant relationship between debt and dividends and, , Zwiebel (1996) and Douglas (2001) confirm that firm value is optimized only when debt and dividends are simultaneously used.
} 
Additionally, as Barclay et al. (1995) point out, the nature of a firm's assets affects both its financing decision making and its dividend policy. Firms with tangible assets can generally more easily access the long-term debt market due to the existence of collateral and the consequent ability to secure debt (Scott, 1977). One would therefore expect firms with a high proportion of tangible assets to be more leveraged, which in turn would affect dividend payments negatively if Hypothesis $2 a$ holds, or positively if Hypothesis $2 b$ is supported. Therefore, two alternative hypotheses concerning the effect of the nature of a firm's assets on its payout ratio should be posed:

Hypothesis 4a: Firms with a high proportion of tangible fixed assets have lower payout ratios (relying on the substitution effect predicted in Hypothesis $2 a$ ).

Hypothesis 4b: Firms with a high proportion of tangible fixed assets have higher payout ratios (relying on the complementarity effect predicted in Hypothesis $2 b$ ).

Finally, a firm's size has traditionally been considered among the determinants of its dividend policy, and previous evidence seems to confirm that larger firms pay higher dividends. There are several arguments justifying the positive relationship between size and payout ratio. For instance, larger firms enjoy better access to the capital markets and, consequently, are less financially constrained, which allows them to pay higher dividends (Holder et al. 1998; Twite, 2001).

Additionally, larger firms are usually mature firms with limited growth opportunities that are prone to paying more dividends to avoid overinvestment (Barclay et al., 1995). Accordingly, Fama and French (2001) show that the largest US firms have higher payout ratios. More recently, Denis and Osobov (2008) provide evidence of the positive relationship between the likelihood of paying dividends and size. This leads to our next hypothesis:

\section{Hypothesis 5: The larger the firm the higher the payout ratios.}

The Catering theory of dividends:

The characteristics of firms that pay dividends (that is, their levels of free cash flow, leverage, earnings, tangible fixed assets, and size) should not be separately analyzed from certain psychological components, in that an important part of the decision to pay dividends may stem from a firm's desire to satisfy investor expectations. This psychological component of dividends is explicitly accounted for in the clientele theory. For instance, Shefrin and Statman (1984) extend the work of Thaler and Shefrin (1981) and develop the "behavioural life cycle" theory of dividends that relies on psychological reasons to explain why investors prefer dividends over capital gains.

Allen and Michaely (2003) argue that the clientele effects are the very reason for the presence of dividends because, as found by Allen et al. (2000), firms paying 
dividends attract relatively more institutional investors and perform better. Polk and Sapienza (2004; 2009), Baker et al. (2003), Ferreira et al. (2010) also rely on behavioral explanations when analyzing the clientele effect.

As we can see, theoretical and empirical dividend models are increasingly incorporating the principles of behavioral finance. Relying on behavioral arguments, Baker and Wurgler (2004a) develop a theory according to which firms cater to their investors' preferences ${ }^{8}$ such that they pay dividends when dividend payers trade at a premium, and do not pay dividends when dividend payers trade at a discount. These authors find an answer as to why no consensus has been reached in the literature about dividends. Specifically, they argue that while the dividend decision may be very important, it is even more important to base the direction of this decision on the prevailing investor sentiment. This argument strongly supports the catering theory of dividends, a new theory according to which investors have sentiments about dividends.

Providing empirical support for this theory, Baker and Wurgler (2004b) show that changes in payout ratios can be explained in terms of what firms denominate as "catering incentives," that is, a measure of market desire for dividend-paying stocks. Specifically, they find a connection between the tendency to pay dividends and catering incentives. These authors use a market-level variable, the "dividend premium," as a proxy for the value that the market places on dividends (i.e., the premium that investors are willing to pay for dividend-paying stocks).

The impact of this variable on the decision to initiate dividend payments shows that changes in a firm's dividend policy may capture changes in investor sentiment about dividend-paying firms relative to their sentiment about nonpaying firms. Based on this finding, these authors develop a behavioral model, according to which the stock price premium carried by dividend-payers explains the decision on whether to pay dividends. Baker and Wurgler (2004b) measure relative investor sentiment about dividend-paying firms by using the difference between the logarithm of the bookvalue-weighted average market-to-book ratio for dividend payers, and the bookvalue-weighted average market-to-book ratio for non-payers. They find a positive relationship between the catering incentives, captured by the dividend premium, and the change in firms' propensity to pay dividends. Relying on this new view of dividends, we take a step forward and propose a measure of catering incentives at the firm level. Therefore, our last hypothesis is as follows:

Hypothesis 6: A firm's payout ratio is positively driven by catering incentives.

\footnotetext{
${ }^{8}$ According to Baker and Wurgler (2004a), the catering theory and the clientele theory differ in that dividends had never been explored via investor sentiment before. Another difference is that the catering theory focuses more on the global level of dividends as the result of the demand for shares that pay dividends.
} 


\section{Data and Variables}

Data:

To test the hypotheses posed in the previous section, we use data from several Eurozone countries. We selected an international database, World scope, as our source of information. Additionally, international data such as the growth of capital goods prices, the rate of interest on short-term debt, and the rate of interest on long-term debt, are extracted from the Main Economic Indicators published by the Organization for Economic Cooperation and Development (OECD).

For each country, we construct an unbalanced panel of nonfinancial firms ${ }^{9}$ whose information is available for a least six consecutive years from 1986 to 2003. This strong requirement is a necessary condition since we lose one year of data in the construction of some variables (Appendix C), we lose another year of data because of the estimation of the model in first differences, and four-consecutive-year data is required in order to test for second-order serial correlation, as Arellano and Bond (1991) point out. We must test for second-order serial correlation because our estimation method, the GMM is based on this assumption.

Three of the 12 Eurozone countries ${ }^{10}$ are excluded from our analysis for various reasons. As in La Porta et al. (2000), Luxembourg is removed from our sample because there are only a small number of firms listed on Luxembourg's stock exchange. Greece is excluded because dividends are mandatory in that country. Finally, Finland had to be excluded because no sample with the abovementioned requirements could be selected. The structure of the samples, by number of firms, and number of observations per country, is provided in Table 1. As shown in Table 2 , the resultant unbalanced panel comprises 635 firms and 6,451 observations. Using an unbalanced panel for a long period (18 years) is the best way to correct for the survival bias caused by some firms being delisted and, consequently, dropped from the database.

Table 1. Structure of the samples by countries

\begin{tabular}{l|c|c|c|c}
\hline Country & $\begin{array}{c}\text { Number of } \\
\text { companies }\end{array}$ & $\begin{array}{c}\text { Percentage of } \\
\text { companies }\end{array}$ & $\begin{array}{c}\text { Number of } \\
\text { observations }\end{array}$ & $\begin{array}{c}\text { Percentage of } \\
\text { observations }\end{array}$ \\
\hline Germany & 110 & 17.32 & 1,153 & 17.87 \\
France & 107 & 16.85 & 1,081 & 16.76 \\
Netherlands & 91 & 14.33 & 943 & 14.62 \\
Spain & 88 & 13.86 & 999 & 15.49 \\
Belgium & 83 & 13.07 & 907 & 14.06
\end{tabular}

\footnotetext{
${ }^{9}$ We restrict our analysis to non-financial firms because financial firms have their own specificity.

${ }^{10}$ The Eurozone currently comprises twelve countries: Austria, Belgium, Finland, France, Germany, Greece, Ireland, Italy, Luxemburg, Netherlands, Portugal, and Spain.
} 


\begin{tabular}{l|l|l|l|l} 
Portugal & 44 & 6.93 & 406 & 6.29 \\
Ireland & 42 & 6.61 & 435 & 6.74 \\
Austria & 38 & 5.98 & 309 & 4.79 \\
Italy & 32 & 5.04 & 218 & 3.38 \\
\hline Total & 635 & 100.00 & 6,451 & 100.00 \\
\hline
\end{tabular}

The table shows extracted data from firms for which information is available for at least five consecutive years between 1986 and 2003. After removing the first-year data, used only to construct several variables (see, for instance, Appendix C), the resultant samples comprise 110 firms (1,153 observations) for Germany, 107 firms (1,081 observations) for France, 91 firms (943 observations) for the Netherlands, 88 firms (999 observations) for Spain, 83 firms (907 observations) for Belgium, 44 firms (406 observations) for Portugal, 42 firms (435 observations) for Ireland, 38 firms (309 observations) for Austria and 32 firms (218 observations) for Italy.

Table 2. Structure of the panel

\begin{tabular}{c|c|c|c|c}
\hline $\begin{array}{c}\text { No. of annual } \\
\text { observations } \\
\text { per company }\end{array}$ & $\begin{array}{c}\text { Number of } \\
\text { companies }\end{array}$ & $\begin{array}{c}\text { Percentage of } \\
\text { companies }\end{array}$ & $\begin{array}{c}\text { Number of } \\
\text { observations }\end{array}$ & Percentage of observations \\
\hline $\mathbf{1 8}$ & 4 & 0.63 & 72 & 1.12 \\
$\mathbf{1 7}$ & 6 & 0.94 & 102 & 1.58 \\
$\mathbf{1 6}$ & 42 & 6.61 & 672 & 10.42 \\
$\mathbf{1 5}$ & 35 & 5.51 & 525 & 8.14 \\
$\mathbf{1 4}$ & 56 & 8.82 & 784 & 12.15 \\
$\mathbf{1 3}$ & 47 & 7.40 & 611 & 9.47 \\
$\mathbf{1 2}$ & 46 & 7.24 & 552 & 8.56 \\
$\mathbf{1 1}$ & 49 & 7.72 & 539 & 8.36 \\
$\mathbf{1 0}$ & 57 & 8.98 & 570 & 8.84 \\
$\mathbf{9}$ & 54 & 8.50 & 486 & 7.53 \\
$\mathbf{8}$ & 63 & 9.92 & 504 & 7.81 \\
$\mathbf{7}$ & 47 & 7.40 & 329 & 5.10 \\
$\mathbf{6}$ & 60 & 9.45 & 360 & 5.58 \\
$\mathbf{5}$ & 69 & 10.87 & 345 & 5.35 \\
\hline Total & 635 & 100.00 & 6,451 & 100.00 \\
\hline
\end{tabular}

Data from firms for which information is available for at least five consecutive years between 1986 and 2003 were extracted. After removing first-year data, used only to construct several variables (Appendix $\mathrm{C}$ ), the resultant unbalanced panel comprises 635 firms $(6,451$ observations $)$.

Table 3. Summary Statistics

\begin{tabular}{|c|c|c|c|c|}
\hline \multicolumn{5}{|c|}{ Panel A. Tobit model to solve dividends censure } \\
\hline Variable & Mean & $\begin{array}{l}\text { Standard } \\
\text { deviation }\end{array}$ & Minimum & Maximum \\
\hline
\end{tabular}




\begin{tabular}{|c|c|c|c|c|}
\hline$P R_{i t}$ & .38363 & .34093 & 0.0000 & 1.0000 \\
\hline$(I / K)_{i t}$ & .05651 & .08761 & -1.14290 & .66487 \\
\hline$(C F / K)_{i t}$ & .03952 & .06031 & -.72767 & .40246 \\
\hline$(\Delta D / K)_{i t}$ & .01271 & .10017 & -1.74563 & 64275 \\
\hline$(\Delta S / K)_{i t}$ & .00433 & .02516 & -.15017 & .87898 \\
\hline \multicolumn{5}{|c|}{ Panel B.Value model to predict catering } \\
\hline Variable & Mean & $\begin{array}{l}\text { Standard } \\
\text { deviation }\end{array}$ & Minimum & Maximum \\
\hline$(V / K)_{i t}$ & .63668 & 68147 & .01405 & 9.2732 \\
\hline$D_{i t}$ & .09959 & .10990 & .0000 & .82617 \\
\hline$(I / K)_{i t}$ & .05651 & .08761 & -1.14290 & .66487 \\
\hline$(C D / K)_{i t}$ & .01399 & .02217 & 0 & .47295 \\
\hline \multicolumn{5}{|c|}{ Panel C. Catering model of dividends } \\
\hline Variable & Mean & $\begin{array}{l}\text { Standard } \\
\text { deviation }\end{array}$ & Minimum & Maximum \\
\hline$F C F_{i t}$ & .05140 & .11449 & -1.9768 & 1.1084 \\
\hline$D_{i t}$ & .09959 & 10990 & .0000 & .82617 \\
\hline$N I_{i t}$ & .02834 & .06211 & -.78456 & .52176 \\
\hline$T A N G_{i t}$ & .28850 & .18704 & .00006 & 98799 \\
\hline$S I_{i t}$ & 12.6993 & 1.7785 & 8.4109 & 18.5011 \\
\hline
\end{tabular}

Table 3 provides summary statistics (mean, standard deviation, minimum, and maximum) of the variables used in the construction of the dependent and explanatory variables. $P R_{i t}$ denotes payout ratio, $(I / K)_{i t}$ denotes investment, $(C F / K)_{i t}$ is cash flow, $(\Delta D / K)_{i t}$ and $(\Delta S / K)_{i t}$ stand for the increment of debt and shares, respectively, $(V / K)_{i t}$ is the firm's value, $D_{i t}$ represents debt ratio, $(C D / K)_{i t}$ denotes common dividends, $F C F_{i t}$ is the free cash flow, $N I_{i t}$ denotes net income, $T A N G_{i t}$ denotes tangible fixed assets, and $S I_{i t}$ is size.

\section{Dependent Variable:}

The dependent variable in our model is the payout ratio, which is a censured variable in that some firms pay dividends, whereas others do not. Note that if we considered only the firms paying dividends, our results would be biased. To solve this problem, we predict the payout ratio using an explanatory model for this variable. We follow the model provided by Auerbach and Hasset (2003), which is based on the equality of sources and uses of funds, and we obtain the following Tobit model that provides us with a prediction of the payout ratio for each period from 1986 to 2003.

$$
C P R_{i t}=\beta_{0}+\beta_{1}(I / K)_{i t}+\beta_{2}(C F / K)_{i t}+\beta_{3}(\Delta B / K)_{i t}+B_{4}(\Delta S / K)_{i t}+\mu_{i t}
$$

with $P R_{i t}=C P R_{\text {it }}$ if $C P R_{i t}>0, P R_{i t}=0$ if $C P R_{i t} \leq 0$

where $C P R_{i t}$ is a latent variable observed only when it is positive, whereas we know only that it is negative in the remainder of the cases. The explanatory variables for the payout ratio are: investment $\left(I_{i t} / K_{i t}\right)$, cash flow $\left(C F_{i t} / K_{i t}\right)$, increment of debt 
$\left(\Delta B_{i t} / K_{i t}\right)$, and increment of shares $\left(\Delta S_{i t} / K_{i t}\right)$. All explanatory variables are scaled by the replacement value of total assets $\left(K_{i t}\right)$, calculated as explained in Appendix A. ${ }^{11}$

Considering that $C P R_{i t}$ follows a normal distribution with mean $\mu$ and variance $\sigma_{2}$, and letting

$\beta_{0}+\beta_{1}(I / K)_{i t}+\beta_{2}(C F / K)_{i t}+\beta_{3}(\Delta B / K)_{i t}+B_{4}(\Delta S / K)_{i t}+\mu_{i t}=X_{i t}^{\prime} \beta$,

then the logarithmic likelihood function of our model is

$\ln L=\sum_{P R_{i t}>0}-\frac{1}{2}\left[\ln (2 \pi)+\ln \sigma^{2}+\frac{\left(P R_{i t}-X_{i t}^{\prime} \beta\right)^{2}}{\sigma^{2}}\right]+\sum_{P R_{i t}=0} \ln \left[1-\Phi\left(\frac{X_{i t}^{\prime} \beta}{\sigma}\right)\right]$,

where the first term picks up the observations for which $P R_{i t}>0$ (that is, observations for which the payout ratio is observable and, consequently, the density function is known), and where the second term refers to the remainder of the observations for which the payout ratio is unobservable, and we assume that the function $\Phi($.$) is$ distributed as $\mathrm{N}(0,1)$.

Table 4 provides summary statistics (mean, standard deviation, minimum and maximum) of the payout ratios obtained by the maximum likelihood estimation of the Tobit model in (1). In addition, the estimation of a Probit model including the same set of explanatory variables allows us to check the capacity of prediction of the model in (1). As shown in the last column of Table 4, the percentages of correct classification are like those reported in previous studies. Additionally, the last row of the table displays the summary statistics of the new variable, $C P R_{i t}$, for which the problem of censure is already solved, and which will be the dependent variable in our model.

Table 4. Summary statistics of the estimated payout ratios

\begin{tabular}{lccccc}
\hline Variable & Mean & $\begin{array}{c}\text { Standard } \\
\text { deviation }\end{array}$ & Minimum & Maximum & $\begin{array}{c}\text { Correct } \\
\text { classification }\end{array}$ \\
\hline CPR86 & .13018 & .42393 & -.57906 & .72013 & 100.00 \\
CPR87 & .30365 & .17033 & -.37441 & .53203 & 87.50 \\
CPR88 & .32129 & .10967 & .03271 & .98574 & 83.66 \\
CPR89 & .32494 & .08542 & -.35601 & .52085 & 85.31 \\
CPR90 & .38818 & .07495 & .05319 & .68173 & 87.63 \\
CPR91 & .40585 & .04784 & .07295 & .58586 & 84.68 \\
CPR92 & .45219 & .13128 & -.97013 & .66520 & 82.51 \\
CPR93 & .40188 & .25357 & -4.1673 & .98977 & 75.29 \\
CPR94 & .28988 & .15638 & -1.5087 & .65421 & 77.16 \\
CPR95 & .30949 & .14072 & -1.3781 & .72779 & 77.46
\end{tabular}

${ }^{11}$ The subscript $i$ refers to the firm and t refers to the time period. 


\begin{tabular}{cccccc} 
CPR96 & .34289 & .13198 & -.84888 & .77060 & 78.96 \\
CPR97 & .28807 & .08769 & -.47661 & .46076 & 79.80 \\
CPR98 & .27967 & .09732 & -.64811 & .50091 & 78.63 \\
CPR99 & .27442 & .12663 & -1.9449 & .39907 & 77.27 \\
CPR00 & .27979 & .06908 & -.29269 & .47720 & 76.36 \\
CPR01 & .38725 & .15393 & -1.0219 & .94066 & 78.72 \\
CPR02 & .35177 & .41456 & -5.1497 & .60144 & 78.45 \\
CPRO3 & .35567 & .22063 & -2.2385 & .89890 & 77.73 \\
\hline CPR total & .34023 & .17056 & -5.14974 & .98977 & \\
\hline
\end{tabular}

This table reports summary statistics of the estimated payout ratios. CPR03, for instance, is the payout ratio estimated by using a Tobit model for the year 2003 to solve the censure problem. Correct classification stands for the percentage of correct classification arising from a Probit model that includes the same set of explanatory variables.

\section{Explanatory Variables:}

According to the theories discussed in Section I.A, the explanatory variables to be entered into our basic model are: free cash flow, leverage, earnings, tangible fixed assets, and size. To capture the potential benefits of dividends as a mechanism to reduce the conflicts of interest between owners and managers with respect to the allocation of the firm's free cash flow, our model incorporates a free cash flow index $\left(F C F_{i t}\right)$, obtained from the interaction of cash flow with the inverse of the investment opportunities. ${ }^{12}$

We compute a firm's cash flow as $C F_{i t}=N I A P D_{i t}+D E P_{i t}$, where $N I A P D_{i t}$ denotes net income after preferred dividends, and $D E P_{i t}$ represents book depreciation expense. Investment opportunities are measured by means of Tobin's q, calculated as $q_{i t}=$ $\left(V_{i t}+P S_{i t}+M V L T D_{i t}+B V S T D_{i t}\right) / K_{i t}$, where $V_{i t}$ is the market value of common stock, $P S_{i t}$ is the value of the firm's outstanding preferred stock, $M V L T D_{i t}$ represents the market value of the long-term debt (see Appendix B), and BVSTD $i t$ stands for the book value of short-term debt.

To investigate whether there is a substitution, or a complementary relationship between debt and dividends, the debt ratio also enters our model. The debt ratio is defined as $D_{i t}=M V L T D_{i t} /\left(V_{i t}+P S_{i t}+B V S T D_{i t}+M V L T D_{i t}\right)$. We use in the numerator the long-term debt, since most arguments in financial theory are related to this type of debt (DeAngelo and DeAngelo, 2006).

To test Lintner's (1956) predictions about the relevance of a firm's earnings for its dividend policy, we include the firm's net income, $N I_{i t}$, in our model, measured as $N I_{i t}=\left(P I_{i t}-I T X_{i t}\right) / K_{i t}$, where $P I_{i t}$ encompasses all income before taxes, and $I T X_{i t}$, represents all taxes levied on income.

\footnotetext{
${ }^{12}$ Details about the interpretation of this index can be found in Miguel and Pindado (2001).
} 
Finally, tangible fixed assets $\left(T A N G_{i t}\right)$ are computed as the net book value of property, plant, and equipment, scaled by the replacement value of total assets, and size $\left(S I_{i t}\right)$ is the natural logarithm of the replacement value of total assets.

In accordance with our aims, our model incorporates a variable capturing investor sentiment. Specifically, we propose the construction of a variable capturing investors' sentiment at the firm-level that acts as a proxy for this catering effect. However, it is difficult to find a variable that captures and measures investor sentiment in an objective or definitive way, since sentiment is inherently subjective. ${ }^{13}$ Given this limitation, our measure should be regarded as a firm-level alternative to the variable originally proposed by Baker and Wurgler (2004b). The starting point for the calculation of this new variable is the following value model

$(V / K)_{i t}=\alpha_{0}+\alpha_{1}(I / K)_{i t}+\alpha_{2} D_{i t}+\alpha_{3}(C D I V / K)_{i t}+\varepsilon_{i t}$,

where $I_{i t}$ represents investment (calculated as described in Appendix C), and CDIV it common dividends. If a firm's market valuation is mainly explained by its investment, debt, and dividend decisions, the error term, $\varepsilon_{i t}$, captures what cannot be explained by these three financial decisions and, consequently, is our proxy for the firm's investor sentiment.

This variable represents our major contribution to the strand of literature pioneered by Baker and Wurgler (2004b). Note that these authors propose a measure of the market desire for dividend-paying stocks or, in other words, a measure at marketlevel of the investor sentiment. Alternatively, we propose a measure of catering incentives at the firm level. If investor sentiment cannot be objectively measured because of its strong psychological component, our proposal is intended to overcome this limitation by proxying catering incentives through a variable built upon the residue of a value model. In this way, a firm's market value is expected to be the result of its main financial decisions, as well as its investor sentiment regarding dividends.

Table 5 provides summary statistics for the resultant catering variable for all years, obtained by cross-sectionally estimating the model in (2). The last row of the table displays the summary statistics of the resultant catering variable, $C A T_{i t}$, which will enter our dividend model.

Table 5. Summary statistics of the estimated catering variable

\begin{tabular}{lllll}
\hline Variable & Mean & $\begin{array}{l}\text { Standard } \\
\text { deviation }\end{array}$ & Minimum & Maximum \\
\hline CAT86 & .0000 & .00741 & -.33190 & .33741
\end{tabular}

\footnotetext{
${ }^{13}$ Baker and Wurgler (2006, pp. 1655) affirm that, "There are no definitive or uncontroversial measures for investor sentiment.
} 


\begin{tabular}{lllll} 
CAT87 & .0000 & .04132 & -.51434 & 2.7364 \\
CAT88 & .0000 & .09847 & -1.2738 & 3.9961 \\
CAT89 & .0000 & .11973 & -1.3468 & 4.4887 \\
CAT90 & .0000 & .14999 & -1.7954 & 7.5654 \\
CAT91 & .0000 & .12923 & -.638263 & 4.9983 \\
CAT92 & .0000 & .10002 & -.674895 & 3.1729 \\
CAT93 & .0000 & .09917 & -1.1421 & 2.6332 \\
CAT94 & .0000 & .12363 & -1.4792 & 4.4738 \\
CAT95 & .0000 & .15705 & -2.1455 & 7.9613 \\
CAT96 & .0000 & .18841 & -2.2141 & 5.2106 \\
CAT97 & .0000 & .17873 & -1.8571 & 5.4364 \\
CAT98 & .0000 & .19392 & -2.1252 & 6.9161 \\
CAT99 & .0000 & .23339 & -1.8219 & 8.1605 \\
CAT00 & .0000 & .18831 & -1.0222 & 7.6399 \\
CAT01 & .0000 & .12530 & -1.0556 & 4.6773 \\
CAT02 & .0000 & .09525 & -2.5362 & 3.4662 \\
CAT03 & .0000 & .10524 & -3.2830 & 3.7791 \\
\hline CAT total & .0000 & .59634 & -3.2830 & 8.1605 \\
\hline
\end{tabular}

This table summarizes statistics of the resultant catering variable for all years, obtained by cross-sectionally estimating the value model in (2). The last row of the table displays the summary statistics of the resultant catering variable, $C A T_{i t}$, which will enter our dividend model. Note that the catering variable comes from the error term of an explanatory value model, and therefore its mean is always zero.

\section{Empirical model and estimation method}

Using the dependent variable obtained as explained in Section II.B, and the traditional explanatory variables described in Section II.C, our basic model is as follows:

$$
C P R_{i t}=\gamma_{0}+\gamma_{1} F C F_{i t}+\gamma_{2} D_{i t}+\gamma_{3} N I_{i t}+\gamma_{4} T A N G_{i t}+\gamma_{5} S I Z E_{i t}+\varepsilon_{i t},
$$

where $\varepsilon_{\mathrm{it}}$ is the random disturbance.

The basic model in (3) can be easily extended to investigate the existence of the catering effect by including the variable $C A T_{i t}$, leading to the following extended model:

$$
C P R_{i t}=\gamma_{0}+\gamma_{1} F C F_{i t}+\gamma_{2} D_{i t}+\gamma_{3} N I_{i t}+\gamma_{4} T A N G_{i t}+\gamma_{5} S I Z E_{i t}+\gamma_{6} C A T_{i t}+\varepsilon_{i t},
$$

Our models are estimated by the panel data methodology. Two issues are considered in making this choice. First, unlike cross-sectional analysis, panel data allow us to control for individual heterogeneity. This point is crucial in our study because the dividend decision is very closely related to the specificity of each firm. In fact, each firm has a different propensity to pay dividends, which could be regarded as 
unobserved heterogeneity. Therefore, to eliminate the risk of obtaining biased results, we control for such heterogeneity by modeling it as an individual effect, $\eta_{I}$, which is then eliminated by taking first differences of the variables. Consequently, the error term in our models, $\varepsilon_{i t}$, is split into four components.

First, the above mentioned individual or firm-specific effect is presented as $\eta_{\mathrm{i}}$. Second, $d_{t}$ measures the time-specific effect by the corresponding time dummy variables, so that we can control for the effects of macroeconomic variables on the dividend decision. Third, since our models are estimated using data from several countries, we also include country dummy variables $\left(c_{i}\right)$. Finally, $v_{i t}$ represents the random disturbance.

The second issue we address by using the panel data methodology is the endogeneity problem. The endogeneity problem is likely to arise in as far as the dependent variable (payout ratio) explains some explanatory variables. For instance, the payout ratio may explain leverage based on arguments used to justify reverse causality. In fact, Jensen et al. (1992), and Mod'd et al. (1998), among others, document a significant effect from dividends on debt.

Additionally, there are reasons to expect size to be endogenous, since, as Ferris et al. (2006) point out, large dividend payers have continued to increase in size over the last 10 years. Consequently, endogeneity may be a problem in our models that must be controlled for. That is why our models have been estimated using instruments. Specifically, we use all the right-hand-side variables in the models lagged from $\mathrm{t}-1$ to $\mathrm{t}-4$ as instruments for the equations in differences, and $\mathrm{t}-1$ for the equations in levels, as Blundell and Bond (1998) suggest, when deriving the system estimator used in this paper.

Finally, we check for potential misspecification of the models. First, we use the Hansen $\mathbf{J}$ statistic of over-identifying restrictions to test for the absence of correlation between the instruments and the error term. Tables 6 and 7 show that the instruments used is valid. Second, we use the $m_{2}$ statistic, developed by Arellano and Bond (1991), to test for lack of second-order serial correlation in the first-difference residual.

Tables 6 and 7 show that there is no problem of second-order serial correlation in our models $\left(\right.$ see $m_{2}$ ). Note that although there is first-order serial correlation (see $m_{1}$ ), this is caused by the first-difference transformation of the model and, consequently, it does not represent a specification problem of the models. Third, the results shown in Tables 6 and 7 provide good outcomes for the following three Wald tests: $z_{1}$ is a test of the joint significance of the reported coefficients; $z_{2}$ is a test of the joint significance of the time dummies; and $z_{3}$ is a test of the joint significance of the country dummies. 
Table 6. Estimation results of the basic and extended models

\begin{tabular}{lll}
\hline & $\mathrm{I}$ & $\mathrm{II}$ \\
\hline Constant & $-.05732^{*}(.018832)$ & $-.02273^{* *}(.01367)$ \\
$F C F_{i t}$ & $.38534^{*}(.01989)$ & $.44124^{*}(.01211)$ \\
$D_{i t}$ & $.23181^{*}(.01269)$ & $.22471^{*}(.00937)$ \\
$N I_{i t}$ & $.22608^{*}(.03379)$ & $.07396^{*}(.02011)$ \\
$T A N G_{i t}$ & $.21719^{*}(.01167)$ & $.21248^{*}(.00925)$ \\
$S_{i t}$ & $.01955^{*}(.00165)$ & $.01682^{*}(.00121)$ \\
$C A T_{i t}$ & & $.01781(.00103)$ \\
$z_{1}$ & $431.30(5)$ & $769.21(5)$ \\
$z_{2}$ & $1277.31(16)$ & $2250.85(16)$ \\
$z_{3}$ & $35.27(8)$ & $64.34(8)$ \\
$m_{1}$ & -3.41 & -3.40 \\
$m_{2}$ & -1.24 & -0.98 \\
Hansen & $428.51(397)$ & $505.19(510)$ \\
\hline
\end{tabular}

The regressions are performed by using the panel described in Table 2 . The variables are defined in Table 3 . The remainder of the information needed to read this table is as follows: i) Heteroscedasticity consistent asymptotic standard error in parentheses. ii) $* * *$, and $* * *$ indicate significance at the $1 \%, 5 \%$ and $10 \%$ levels, respectively; iii) $\mathrm{z}_{1}, \mathrm{z}_{2}$ and $\mathrm{z}_{3}$ are Wald tests of the joint significance of the reported coefficients, of the time dummies, and of the country dummies, respectively, asymptotically distributed as $\chi^{2}$ under the null of no significance, with degrees of freedom in parentheses; iv) $m_{i}$ is a serial correlation test of order $\mathrm{i}$ using residuals in first differences, asymptotically distributed as $\mathrm{N}(0,1)$ under the null of no serial correlation; v) Hansen is a test of the over-identifying restrictions, asymptotically distributed as $\chi^{2}$ under the null of no correlation between the instruments and the error term, degrees of freedom in parentheses.

Table 7. Estimation results of the moderating role of certain firm characteristics

\begin{tabular}{|c|c|c|c|}
\hline & I & II & III \\
\hline Constant & $\begin{array}{l}.0484 * * * \\
(.02764)\end{array}$ & $\begin{array}{l}-.06136^{* * *} \\
(.02651)\end{array}$ & $.08452(.02806)$ \\
\hline$F C F_{i t}$ & $\begin{array}{l}.40301^{*} \\
(.01329)\end{array}$ & $.39978 *(.01285)$ & $\begin{array}{l}.41178 * \\
(.01399)\end{array}$ \\
\hline$D_{i t}$ & $\begin{array}{l}.23441^{*} \\
(.01239)\end{array}$ & $.37364 *(.01391)$ & $\begin{array}{l}.21581^{*} \\
.01224)\end{array}$ \\
\hline$N I_{i t}$ & $\begin{array}{l}.10179 * \\
(.02114)\end{array}$ & $.13973 *(.02194)$ & $\begin{array}{l}.05817^{*} \\
(.02238)\end{array}$ \\
\hline$T A N G_{i t}$ & $\begin{array}{l}.27127^{*} \\
(.01118)\end{array}$ & $.27764 *(.01167)$ & $\begin{array}{l}.25512 * \\
(.01145)\end{array}$ \\
\hline$S_{i t}$ & $\begin{array}{l}.02595^{*} \\
(.00220)\end{array}$ & $.03002 *(.00219)$ & $\begin{array}{l}.02414^{*} \\
(.00227)\end{array}$ \\
\hline$C A T_{i t}$ & $.00446(.00273)$ & $\begin{array}{l}-.13649^{*} \\
(.00584)\end{array}$ & $\begin{array}{l}.01104 * \\
(.00135)\end{array}$ \\
\hline
\end{tabular}




\begin{tabular}{llll}
$C A T_{i t} D V_{i t}$ & $.02325^{*}$ & $.18262^{*}$ & $.06480^{*}$ \\
$t$ & $(.00330)$ & $(.00647)$ & $(.06480)$ \\
$z_{1}$ & & 25.07 & 14.75 \\
$z_{2}$ & $618.18(7)$ & $586.61(7)$ & $411.58(7)$ \\
$z_{3}$ & $1702.17(16)$ & $1674.44(16)$ & $1552.86(16)$ \\
$m_{1}$ & $146.34(8)$ & $131.17(8)$ & $166.17(8)$ \\
$m_{2}$ & -3.39 & -3.42 & -3.39 \\
Hansen & -.80 & -0.43 & -1.09 \\
\hline
\end{tabular}

The regressions are performed using the panel described in Table 2. $D V_{i t}$ is a dummy variable that takes the following values: a) 1 if the level of liquid assets is above the sample median, and 0 otherwise in Column I; b) 1 if Tobin's q is higher than unity, and 0 otherwise in Column II; c) 1 if the free cash flow is above the sample median, and 0 otherwise in Column III. The remainder of the variables is defined in Table 3.

The remainder of the information needed to read this table is as follows: i) Heteroscedasticity consistent asymptotic standard error in parentheses. ii) *,**, and $* * *$ indicate significance at the $1 \%, 5 \%$, and $10 \%$ levels, respectively; iii) $t$ is the $\mathrm{t}-$ statistic for the linear restriction test under the null hypothesis of no significance; iv) $\mathrm{z}_{1}, \mathrm{z}_{2}$ and $\mathrm{z}_{3}$ are Wald tests of the joint significance of the reported coefficients, of the time dummies, and of the country dummies, respectively, asymptotically distributed as $\chi^{2}$ under the null of no significance, with degrees of freedom in parentheses; v) $\mathrm{m}_{\mathrm{i}}$ is a serial correlation test of order $\mathrm{i}$ using residuals in first differences, asymptotically distributed as $\mathrm{N}(0,1)$ under the null of no serial correlation; vi) Hansen is a test of the over-identifying restrictions, asymptotically distributed as $\chi^{2}$ under the null of no correlation between the instruments and the error term, degrees of freedom in parentheses.

\section{Results}

In this section, we first present the results of our basic model in Eq. (3), which includes the explanatory variables that have been traditionally considered determinants of a firm's payout ratio. We then extend this basic model by incorporating a variable capturing investor sentiment into model (4). Finally, we test the implications of the catering theory by means of several firm characteristics, three in particular: liquid assets, investment opportunities, and free cash flow.

\section{Results of the basic and extended models:}

The results for the GMM estimation of our basic model in (3) are provided in Column I of Table 6. Consistent with Hypothesis 1, the level of a firm's free cash flow positively affects its payout ratio. Therefore, consistent with Jensen's (1986) theory, we find that firms with higher levels of free cash flow are encouraged to pay more dividends to restrain manager discretion, and to prevent them from overinvesting. In agreement with Jensen (1989), the coefficient of leverage is 
positive, and suggests that debt and dividends are complementary agency-cost control mechanisms.

Therefore, our evidence supports Hypothesis 2b, according to which a new issue of debt requires a higher dividend payment to limit managerial discretion over the new funds and, consequently, to avoid overinvestment in the firm. The positive relationship between a firm's earnings and its payout ratio predicted in Hypothesis 3 is confirmed by our results. Consistent with Lintner (1956), firms in our sample increase their payout ratios when their earnings rise, to get a stable pattern of dividends and to avoid dividend cuts.

Regarding the nature of the firm's assets, Hypothesis $4 b$ holds, which supports the above-mentioned results concerning the complementary relationship between debt and dividends. That is, firms with more tangible fixed assets are more leveraged and, consequently, maintain larger payout ratios to control the new funds. Finally, and as expected, the positive coefficient on size supports Hypothesis 5, according to which larger firms pay higher dividends. Column II of Table 6 presents the results of the GMM estimation of Model (4). As shown in this table, the signs of the coefficients of the variables included in the basic model remain identical once the catering effect, $C A T_{i t}$, is entered the model. In short, a firm's payout ratio is positively affected by its level of free cash flow, its leverage, its net income, its level of tangible fixed assets, and its size.

Regarding the influence of a firm's investor sentiment on its payout ratio, the positive coefficient of the catering variable confirms Hypothesis 6. Consistent with Baker and Wurgler (2004b), this finding highlights the link between the propensity to pay dividends and catering incentives. In other words, our result suggests that firms cater to their investors' preferences such that they are more prone to increase payout ratios when investors exhibit preference for dividends. This evidence provides empirical support for the catering model previously documented in US firms by Baker and Wurgler (2004a, b), and Li and Lie (2006), among others. Moreover, this result confirms that, as suggested by Von Eije and Megginson (2008), delving into the intricacies of measuring the catering effect may lead the catering theory to become as relevant in European countries as it is in the US.

\section{The moderating role of some firm characteristics:}

After corroborating the existence of a catering effect with our results, we go a step further, and investigate whether certain firm characteristics moderate this effect. We then propose a test of the moderating role played by three features - namely, liquid assets, investment opportunities, and free cash flow. It is worth noting that, as far as we know, there is no prior evidence supporting this view, and providing empirical support for this issue is thus one of the major contributions of this paper. Despite the lack of previous evidence, there are strong arguments that lead us to contend that investor preference for dividends changes in accordance with the above-mentioned characteristics. 
First, Pinheiro et al. (2006) extend the model of Fama and French (2001) by adding a measure of liquid assets, and they find that firms are more likely to pay dividends if they have more liquid assets. Furthermore, these authors' results indicate that the decision to pay dividends depends directly on how much importance a firm's managers attach to shareholder preferences and on the firm's level of liquid assets. This leads us to expect that a firm's liquid assets and its investor sentiment about dividends could be related. Specifically, we expect investor preference for dividends to increase with a firm's liquid assets.

Second, it has been widely documented that dividends convey information about a firm's prospects (Bhattacharya, 1979; John and Williams, 1985; Miller and Rock, 1985). According to signaling arguments, investors are optimistic about firms initiating or increasing dividends in that they interpret such a decision as meaning that there are valuable investment opportunities that guarantee the future distribution of such funds. Additionally, the managerial discretion associated with a high level of intangibles in the firm may make dividends more desirable for investors, to control for such discretion. Overall, this leads us to expect investor preference for dividends to be stronger for firms with valuable investment opportunities.

Third, as commented before the free cash flow theory proposes that dividends lessen the agency costs deriving from the conflicts of interest between managers and owners with respect to a firm's free cash flow. This theory suggests a positive relationship between dividends and the level of free cash flow, a relation that is confirmed by the results presented in the previous section. Based on this result and given the proven role of dividends in controlling for overinvestment processes, we expect investor preference for dividends to be stronger for firms with high levels of free cash flow.

To investigate whether these firm characteristics moderate the catering effect, we propose the following model to be estimated

$$
C P R_{i t}=\gamma_{0}+\gamma_{1} F C F_{i t}+\gamma_{2} D_{i t}+\gamma_{3} N I_{i t}+\gamma_{4} T A N G_{i t}+\gamma_{5} S I Z E_{i t}+C A T_{i t}\left(\gamma_{6}+\lambda D V_{i t}\right)+\varepsilon_{i t}
$$

where $D V_{i t}$ is a dummy variable constructed according to the firm's level of liquid assets, investment opportunities, and free cash flow. It is worth noting that in all cases whenever the dummy variable equals one and both parameters $\left(\gamma_{6}\right.$ and $\left.\lambda\right)$ are significant, a linear restriction test is needed to know whether their sum $\left(\gamma_{6}+\lambda\right)$ is significantly different from zero. The null hypothesis to be tested in these cases is the hypothesis of no significance, $H_{0}: \gamma_{6}+\lambda=0$. Column I of Table 7 reports the results of the model, including the interaction of catering with liquid assets. ${ }^{14}$ In this

\footnotetext{
${ }^{14}$ This variable stands for money available for use in the normal operations of the firm, scaled by the replacement value of total assets; it represents the most liquid of all of the firm's assets.
} 
case, $D V_{i t}$ takes value one if the firm's level of liquid assets is above the sample median, and zero otherwise. In this way, the coefficient of the catering variable is $\gamma_{6}$ for firms with low levels of liquid assets (since $D V_{i t}$ takes value zero), and $\gamma_{6}+\lambda$ for firms with high levels of liquid assets (since $D V_{i t}$ takes value one). As shown in the table, there is no effect from a firm's investor sentiment on its payout ratio when the firm has low liquid assets ( $\gamma_{6}$ not significantly different from zero).

However, the effect is positive and significant for firms with high levels of liquid assets $\left(\gamma_{6}+\lambda=\lambda=0.02325\right.$, significantly different from zero), which confirms that, as expected, investor preference for dividends increases with liquid assets. That is, our evidence suggests that investor demand for dividends translates into higher payout ratios only in those firms with high liquid assets, whereas firms with low liquid assets do not seem to cater to investor preferences.

The interaction of the catering effect and investment opportunities is tested in the model presented in Column II of Table 7. In this model, $D V_{i t}$ takes value one if the firm's Tobin's q is higher than one, and zero otherwise. As shown in the table, the catering effect is negative in firms with non-valuable investment opportunities $\left(\gamma_{6}=-\right.$ 0.13649), whereas this effect turns positive for firms with valuable investment opportunities $\left(\gamma_{6}+\lambda=0.04613\right.$, significantly different from zero, see $\left.t\right)$.

These results point out that the expected catering effect clearly manifests itself when there are prospects for the firm, which affords managers the opportunity to exploit the potential divergence between inside and market expectations, and which makes dividends more valuable to investors. In contrast, non-valuable investment opportunities prevent firms from catering to investor sentiment about dividends, probably because the lack of positive NPV projects may lead to not being able to maintain high payout ratios in the future.

Finally, we investigate the interaction between the catering effect and the free cash flow by estimating the model presented in Column III of Table 7 . In this case, $D V_{i t}$ takes value one if the firm's free cash flow is above the sample median, and zero otherwise. As can be seen in the table, the coefficient of the catering variable is higher for firms with high levels of free cash flow $\left(\gamma_{6}+\lambda=0.07584\right.$, significantly different from zero, see $t$ ) than for firms with low levels of free cash flow $\left(\gamma_{6}=0.01104\right)$. Therefore, it seems that catering incentives (i.e., investor preference for dividend-paying) manifests more strongly in firms with high levels of free cash flow, in which dividends are much more valuable as an agency-cost control mechanism. This evidence again supports Jensen's (1986) theory.

Overall, this evidence provides an excellent robustness check for the results of the basic and extended models, since the sign of the coefficients of both the traditional explanatory variables, and the catering variable remain identical once we control for the moderating role of certain firm characteristics. 


\section{Conclusions}

This paper provides a test of the predictions of the catering theory of dividends by proposing a new approach for analyzing the effect that investor sentiment exerts on corporate dividend policy. Accordingly, a traditional dividend model is extended to incorporate an original measure of the catering effect at the firm-level, proxied by the error term of a market valuation model.

Our results show that investor sentiment impacts payout ratios in Eurozone member countries after controlling for traditional determinants of dividends, such as the free cash flow, leverage, earnings, tangible fixed assets, and size. This finding seems to indicate that dividend policies are driven to some extent by investor sentiment, thus revealing the desire of firm managers to cater to such preferences. Therefore, our evidence provides empirical support for a psychological component in the decision to pay in Eurozone firms, and it thus provides empirical support for the catering model.

Furthermore, this study contributes to an understanding of the implications of catering incentives for dividend policies by examining the moderating role played by certain firm characteristics. Our findings corroborate that the way in which investors appreciate dividend payments depends on the firm's liquid assets, investment opportunities, and free cash flow.

First, investor preference for dividends translates into higher payout ratios only in those firms with high liquid assets.

Second, investor sentiment positively impacts the payout ratio of only those firms with valuable investment opportunities, for which investors' manifest stronger expectations about receiving higher dividends.

Finally, a firm's free cash flow is a driving force behind investor preference for dividends, which is stronger in firms with higher levels of free cash flow in that dividends are probably much more valuable as a mechanism to avoid overinvestment.

An interesting question that is left unanswered by this research is what drives the changes in investors' preferences for dividends before different economic cycles. We leave this as an interesting topic for future research.

\section{Appendix A-Replacement Value of Total Assets}

The replacement value of total assets is obtained as follows:

$$
K_{i t}=R F_{i t}+\left(T A_{i t}-B F_{i t}\right)
$$


where $R F_{i t}$ is the replacement value of tangible fixed assets, $T A_{i t}$ is the book value of total assets, and $B F_{i t}$ is the book value of tangible fixed assets. The latter two variables are obtained from the firm's balance sheet and the first is calculated according to the proposals of Perfect and Wiles (1994)

$R F_{i t}=R F_{i t-1}\left[\frac{1+\phi_{t}}{1+\delta_{i t}}\right]+I_{i t}$

for $\mathrm{t}>\mathrm{t}_{0}$, and $R F_{i t 0}=B F_{i t}$, where $\mathrm{t}_{0}$ is the first year of the chosen period, in our case 1986 . On the other hand, $\delta_{i t}=D_{i t} / B F_{i t}$ and $\phi_{t}=\left(G C G P_{t}-G C G P_{t-1}\right) / G C G P_{t-1}$, where $G C G P_{t}$ is the growth of capital goods prices extracted from the Main Economic Indicators, published by the Organization for Economic Cooperation and Development (OECD).

\section{Appendix B-Market Value of Long-term debt}

The market value of long-term debt, $M V L T D_{i t}$, is obtained from the following formula:

$$
\text { MVLTD }_{i t}=\left[\frac{1+l_{i t}}{1+i_{l}}\right] B V L T D_{i t}
$$

where $B V L T D_{i t}$ is the book value of the long-term debt, $i_{l}$ is the rate of interest of the long-term debt reported in the OECD-Main Economic Indicators and $l_{i t}$ is the average cost of long-term debt, defined as $l_{i t}=\left(I P L T D_{i} / B V L T D_{i t}\right)$, where $I P L T D_{i t}$ is the interest payable on the long-term debt, which is obtained by distributing the interest payable between the short and long-term debt depending on interest rates. That is,

$$
I P L T D_{i t}=\frac{i_{l} B V L T D_{i t}}{i_{S} B V S T D_{i t}+i_{l} B V L T D_{i t}} I P_{i t}
$$

where $I P_{i t}$ is the interest payable, $i_{s}$ is the rate of interest of the short-term debt, also reported in Main Economic Indicators, and $B V S T D_{i t}$ is the book value of the short-term debt.

\section{Appendix C-Investment}

Investment is calculated according to the proposal by Lewellen and Badrinath (1997) as follows:

Let $F A_{i t}$ be the gross book value of the tangible fixed assets of the period $t, R_{i t}$ the gross book value of the old assets retired during the year $t, A B D_{i t}$ the accumulated book depreciation for the year $t$, and $B D_{i t}$ the book depreciation expense corresponding to year $t$. We then have the following equalities:

$F A_{i t}=F A_{i t-1}+I_{i t}-R_{i t}$

(A.1)

$A B D_{i t}=A B D_{i t-1}+B D_{i t}-R_{i t}$

(A.2)

If we solve Eq. A.2 for $R_{i t}$ and substitute it into Eq. A.1, we obtain A.3, 
$F A_{i t}=F A_{i t-1}+I_{i t}+A B D_{i t}-A B D_{i t-1}-B D_{i t}$

(A.3)

Realigning terms, Eq. A.3 is transformed into expression A.4, $F A_{i t}-A B D_{i t}=F A_{i t-1}-A B D_{i t-1}+I_{i t}-B D_{i t}$

(A.4)

As for $F A_{i t}-A B D_{i t}=N F_{i t}$, i.e., the net fixed assets, the former equation can be rewritten more compactly as in Eq. A.5,

$N F_{i t}=N F_{i t-1}+I_{i t}-B D_{i t}$,

(A.5)

from which we obtain the value of investment

$I_{i t}=N F_{i t}-N F_{i t-1}+B D_{i t}$.

(A.6)

\section{References:}

Aivazian, V., Booth, L. and Cleary, S. 2003. Do emerging market firms follow different dividend policies than firms in the U.S: evidence from 8 emerging markets. Journal of Financial Research, 26, 371-387.

Allen, F., Bernardo, W. and Welch, I. 2000. A theory of dividends based on tax clientele. Journal of Finance, 55, 2499-2536.

Allen, F. and Michaely, R. 2003, Payout Policy, in G. Constantinides, M. Harris, and R. Stulz Eds., Handbook of the Economics of Finance, 1A, Amsterdam, Elsevier.

Amihud, Y. and Li, K. 2006. The declining information content of dividend announcements and the effect of institutional holdings. Journal of Financial and Quantitative Analysis, 41, 637-660.

Arellano, M. and Bond, S. 1991. Some tests of specification for panel data: Monte Carlo evidence and an application to employment equations. Review of Economic Studies, 58, 277-297.

Auerbach, A. and Hassett, K. 2003. On the marginal source of investment funds. Journal of Public Economics, 87, 205-232.

Baker, M. and Stein, J. 2003. Market Liquidity as a Sentiment Indicator. Journal of Financial Markets, 7, 271-299.

Baker, M. and Wurgler, J. 2004a. A catering theory of dividends. Journal of Finance, 59, 1125-1165.

Baker, M. and Wurgler, J. 2004b. Appearing and disappearing dividends: The link to catering incentives. Journal of Financial Economics, 73, 271-288.

Baker, M., Stein, J. and Wurgler, J. 2003. When Does the Market Matter? Stock Prices and the Investment of Equity-Dependent Firms. Quarterly Journal of Economics, 118, 969-1006.

Baker, M. and Wurgler, J. 2006. Investor Sentiment and the Cross-section of Stock Returns. Journal of Finance, 61, 1645-1680.

Banerjee, S., Gatchev, V. and Spindt, P. 2007. Stock Market Liquidity and Firm Dividend Policy. Journal of Financial and Quantitative Analysis, 42, 369-398.

Barberis, N., Shleifer, A. and Wurgler, J. 2005. Comovement. Journal of Financial Economics, 75, 283-317.

Barberis, N. A. Shleifer, A. and Vishny, R. 1998. A model of investor sentiment. Journal of Financial Economics, 49, 307-343.

Barclay, M., Smith, C. and Watts, R. 1995. The determinants of corporate leverage and 
dividend policies. Journal of Applied Corporate Finance, 7, 4-19.

Bathia, D. and Bredin, D. 2013. An examination of investor sentiment effect on G7 stock market returns. The European Journal of Finance, 19(9), 909-937.

Benartzi, S., Roni, M. and Thaler, R. 1997. Do changes in dividends signal the future or the past? Journal of Finance, 52, 1007-1034.

Bhattacharya, S. 1979. Imperfect Information, Dividend Policy, and The Bird in the Hand Fallacy. The Bell Journal of Economics, 10, 259-270.

Black, F. and Scholes, M. 1974. The effects of dividend yield and dividend policy on common stock prices and returns. Journal of Financial Economics, 1, 1-22.

Blundell, R. and Bond, S. 1998. Initial conditions and Moment Restrictions in Dynamic Panel Data Models. Journal of Econometrics, 87, 115-144.

Boot, A., Gopalan, R. and Thakor, A. 2008. Market Liquidity, Investor Participation, and Managerial Autonomy: Why do Firms Go Private? Journal of Finance, 63, 20132059.

Boudoukh, J., Michaely, R., Richardson, M. and Roberts, M. 2007. On the implications of measuring payout yield: Implications for empirical asset pricing. Journal of Finance, 62, 877-915.

Brav, A., Graham, J., Harvey, C. and Michaely, R. 2005. Payout policy in the 21st Century. Journal of Financial Economics, 77, 483-527.

Bulan, L., Subramanian, N. and Tunlu, L. 2007. On the timing of dividend initiations. Financial Management, 36, 31-65.

Chakraborty, A., Kazarosian, M. and Trahan, E. 1999. Uncertainty in Executive Compensation and Capital Investment: A Panel Study. Financial Management, 28, 126-139.

Chaplinsky, S. and Niehaus, G. 1993. Do Inside Ownership and Leverage Share Common Determinants? Quarterly Journal of Business and Economics, 32, 61-78.

Chen, S.S. and Ho, K. 1997. Market Response to Product-Strategy and Capital- Expenditure Announcements in Singapore: Investment Opportunities and Free Cash Flow. Financial Management, 26, 82-88.

Coval, J., Stein, J and Baker, M. 2008. Corporate Financing Decisions When Investors Take the Path of Least Resistance. Journal of Financial Economics, 84, 266-298.

Daniel, K., Hirshleifer, D. and Subrahmanyam, A. 1998. Investor Psychology and Security Market Under-and Over-reactions. Journal of Finance, 53, 1839-1885.

DeAngelo, H. and DeAngelo, L. 2006. The irrelevance of the MM dividend irrelevance Theorem. Journal of Financial Economics, 79, 293-316.

DeAngelo, H. and DeAngelo, L. 2007. Payout policy pedagogy: What matters and why. European Financial Management, 13, 11-27.

DeAngelo, H., DeAngelo, L. and Skinner, D. 2004. Are dividends disappearing? Dividend concentration and the consolidation of earnings. Journal of Financial Economics, 72, 425-456.

DeAngelo, H., DeAngelo, L. and Stulz, R. 2004. Dividend Policy, Agency Costs and Earned Equity. University of Southern California, NBER Working paper.

De Jong, A., Duca, E. and Dutordoir, M. 2013. Do Convertible Bond Issuers Cater to Investor Demand? Financial Management, 42, 41-78.

Del Brio, E., Perote, J. and Pindado, J. 2003. Measuring the impact of corporate investment Announcements on share prices: the Spanish experience. Journal of Business, Finance and Accounting, 30, 715-747.

Denis, D. and Osobov, I. 2008. Why Do Firms Pay Dividends? International Evidence on the Determinants of Dividend Policy. Journal of Financial Economics, 89, 62-82. 
Douglas, A. 2001. Managerial replacement and corporate financial policy with endogenous manager-specific value. Journal of Corporate Finance, 7, 25-52.

Easterbrook, F. 1984. Two agency-cost explanations of dividends. American Economic Review, 74, 650-659.

Eckbo, B. and Verma, S. 1994. Managerial share ownership, voting power, and cash dividend policy. Journal of Corporate Finance, 1, 33-62.

Edmans, A., García, D. and Norli, O. 2007. Sports sentiment and stock returns. Journal of Finance, 62, 1967-1998.

Fama, F. and French, K. 2001. Disappearing dividends: Changing firm characteristics or lower propensity to pay? Journal of Financial Economics, 60, 3-44.

Fangjian, F. 2010. Overinvestment and the Operating Performance of SEO Firms. Financial Management, 39, 249-272.

Ferreira, M., Massa, M. and Matos, P. 2010. Dividend Clienteles Around the World Evidence from Institutional Holdings. University of Southern California, Working Paper.

Ferris, S., Sen, N. and Yui, H. 2006. God Save the Queen and her dividends: Corporate payouts in the UK. Journal of Business, 79, 1149-1173.

Ferris S., Jayaraman, N. and Sabherwal, S. 2009. Catering effects in corporate dividend policy: the international evidence. Journal of Banking and Finance, 33, 1730-1738.

Grossman, S. and Hart, O. 1980. Takeover bids, the free - rider problem, and the theory of the corporation. Bell Journal of Economics, 11, 42-64.

Harris, M. and Raviv, A. 1991. The theory of capital structure. Journal of Finance, 46, 297355.

Hoberg, G. and Prabhala, N. 2009. Disappearing dividends, catering, and risk. Review of Financial Studies, 22, 79-116.

Holder, M., Langrehr, F. and Hexter, L. 1998. Dividend Policy Determinants. An Investigation of the Influences of Stakeholder Theory. Financial Management, 27, 73-82.

Hong, H. and Stein, J. 1999. A Unified Theory of underreaction, momentum trading and overreaction in asset markets. Journal of Finance, 54, 2143-2184.

Jegadeesh, N. and Titman, S. 2001. Profitability of Momentum Strategies. An Evaluation of Alternative Explanations. Journal of Finance, 56, 699-720.

Jensen, M. 1986. Agency costs of free cash flow, corporate finance, and takeovers. American Economic Review, 76, 323-329.

Jensen, M. 1989. Eclipse of the public corporation. Harvard Business Review, 89, 61-84.

Jensen, G., Solberg, D. and Zorn, T.1992. Simultaneous Determination of Insider Ownership, Debt, and Dividend Policies. The Journal of Financial and Quantitative Analysis, 27, 247-263.

John, K. and Williams, J. 1985. Dividends, dilution, and taxes: A signalling equilibrium. Journal of Finance, 40, 1053-1070.

John, K. and Senbet, L. 1998. Corporate Governance and Board Effectiveness. Journal of Banking and Finance, 22, 371-403.

Koch, A. and Sun, A. 2004. Dividend changes and the persistence of past earnings Changes. Journal of Finance, 59, 2093-2116.

Kumar, A. and Lee, C. 2006. Retail Investor Sentiment and Return Comovements. Journal of Finance, 61, 2451-2486.

Kuo, J.M., Philip, D. and Zhang, Q. 2013. What drives the disappearing dividends phenomenon? Journal of Banking \& Finance, 37, 3499-3514.

Kurov, A. 2008. Investor Sentiment, Trading Behavior and Informational Efficiency in 
Index Futures Markets. Financial Review, 43, 107-127.

Lamont, O. and Stein, J. 2006. Investor sentiment and corporate finance: Micro and Macro. American Economic Review, 96, 147-151.

La Porta, R., Lopez-de-Silanes, F., Shleifer, A. and Vishny, R. 2000. Investor Protection and Corporate Governance. Journal of Financial Economics, 58, 3-28.

Lewellen, W. and Badrinath, S. 1997. On the measurement of Tobin's Q. Journal of Financial Economics, 44, 77-122.

Li, K. and Zhao, X. 2008. Asymmetric Information and Dividend Policy. Financial Management, 37, 673-694.

Li, W. and Lie, E. 2006. Dividends changes and catering incentives. Journal of Financial Economics, 80, 293-308.

Lintner, J. 1956. Distribution of incomes of corporations among dividends, retained earnings, and taxes. American Economic Review, 46, 97-113.

Manconi, A. and Massa, M. 2013. A Servant to Many Masters: Competing Shareholder Preferences and Limits to Catering. Journal of Financial and Quantitative Analysis, 48, 1693-1716.

Miguel, A. and Pindado, J. 2001. Determinants of Capital Structure: New Evidence from Spanish Panel Data. Journal of Corporate Finance, 7, 77-99.

Miguel, A., Pindado, J. and Torre, C. 2005. How do entrenchment and expropriation phenomena affect control mechanisms? Corporate Governance: An International Review, 13, 505-516.

Miller, M. and F. Modigliani, 1961, "Dividend Policy, Growth and the Valuation of Shares", Journal of Business 34, 411-433.

Miller, M. and Rock, K. 1985. Dividend policy under asymmetric information. Journal of Finance, 40, 1031-1051.

Moh'd, M., Perry, L. and Rimbey, J. 1995. An Investigation of the Dynamic Relationship between Agency Theory and Dividend Policy. Financial Review, 30, 367-385.

Moh'd, M., Perry, L. and Rimbey, J. 1998. The Impact of Ownership Structure on Corporate Debt Policy: A Time-Series Cross-Sectional Analysis. Financial Review, 33, 85-98.

Morgado, A. and Pindado, J. 2003. The underinvestment and overinvestment hypothesis: an analysis using panel data. European Financial Management, 9, 163-177.

Nissim, D. and Ziv, A. 2001. Dividend Changes and Future Profitability. Journal of Finance, 56, 2111-2134.

Perfect, S. and Wiles, K. 1994. Alternative constructions of Tobin's Q: an empirical Comparison. Journal of Empirical Finance, 1, 313-341.

Pinheiro, M., Deniz, I. and Paula, A. 2006. Liquidity and Payout Policy. Princeton University Working Paper.

Polk, C. and Sapienza, P. 2004. The real effects of investor sentiment. NBER Working Paper.

Polk, C. and Sapienza, P. 2009. The Stock Market and Corporate Investment: A Test of Catering Theory. Review of Financial Studies, 22, 187-217.

Ritter, J. 2003. Behavioral Finance. Pacific-Basian Finance Journal, 11, 429-437.

Ross, S. 1977. The determination of financial structure: the incentive signalling approach. Bell Journal of Economics, 8, 23-40.

Rozeff, M. 1982. Growth, beta and agency costs as determinants of dividend payout Ratios. Journal of Financial Research, 5, 249-259.

Scott, J. 1977. Bankruptcy secured debt and optimal capital structure. Journal of Finance, $32,1-19$. 
Shefrin, H. and Statman, M. 1984. Explaining investor preference for cash dividends. Journal of Financial Economics, 13, 253-282.

Skinner, D. 2008. The Evolving Relation between Earnings, Dividends, and Stock Repurchases. Journal of Financial Economics, 87, 582-609.

Subrahmanyam, A. 2007. Behavioural Finance: A Review and Synthesis. European Journal of Financial Management, 14, 12-29.

Thaler, R. and Shefrin, H. 1981. An economic theory of self-control. Journal of Political Economy, 89, 392-406.

Tetlock, P. 2007. Giving Content to Investor Sentiment: The Role of Media in the Stock Market. Journal of Finance, 62, 1139-1168.

Twite, G. 2001. Capital structure choices and taxes: evidence from the Australian dividend imputation tax system. International Review of Finance, 2, 217-234.

Vieira, E. 2011. Investor sentiment and the market reaction to dividend news: European Evidence. Managerial Finance, 37, 1213-1245.

Von Eije, H. and Megginson, W. 2008. Dividends and share repurchases in the European Union. Journal of Financial Economics, 89, 347-374.

Wang, Y., Keswani, A. and Taylor, S. 2006. The Relationships between Sentiment Returns and Volatility. International Journal of Forecasting, 22, 109-123.

Zwiebel, J. 1996. Dynamic capital structure under managerial entrenchment. American Economic Review, 86, 1197-1215. 